\title{
FAKTOR RISIKO STUNTING PADA ANAK USIA 2-5 TAHUN DI WILAYAH GUNUNG DAN PESISIR PANTAI
}

\section{Risk Factors of Stunting among Children Aged 2-5 Years in Ridge And Coastal}

\author{
Agnes Rihi Leo ${ }^{1}$, Hertanto W Subagyo ${ }^{2}$, Martha I Kartasurya ${ }^{3}$ \\ ${ }^{1}$ Departemen Gizi, Fakultas Kedokteran Universitas Diponegoro, Semarang. \\ ; Program studi S1 Ilmu Gizi STIKES Nusantara Kupang. Email: nes_rihileo@yahoo.co.id \\ ${ }^{2}$ Fakultas Kedokteran Universitas Diponegoro. Semarang. \\ ${ }^{3}$ Fakultas Kesehatan Masyarakat Universitas Diponegoro. Semarang
}

\begin{abstract}
The purpose of this study is to analyze the differences risk factors of stunting among children aged 2-5 years in ridge and coastal. Study using cross sectional design. Number of subject is 114 subjects in plateau and 114 subjects in coastal chossed with purposive and consist of 57 stunted and 57 non-stunted. The risk factors of stunting in the ridge is a low of protein adequacy level $(P R=4,8 ; 95 \% C I=2,096-10,99)$, low of Zn adequacy level $(P R=2,827 ; 95 \% C I=1,499-5,322)$, low of Fe adequacy level $(P R=3,766 ; 95 \% C I=1,785-7,944)$, and non-exclusive breastfeeding $(P R=1,626 ; 95 \% C I=1,15-2,299)$. Risk factors of stunting in coastal is low of energy adequacy level $(P R=3,463 ; 95 \% C I=1,648-7,278)$, low of $Z n$ adequacy level $(P R=1,973 ; 95 \%$ $C I=1282-3,038)$, and low of Fe adequacy level $(P R=2,033 ; 95 \% C I=1,003-4,120)$. Risk factors associated most strongly with stunting in the ridge area is a non-exclusive breastfeeding and low of protein adequacy level. The risk factors most strongly associated with stunting in coastal areas is low of protein adequacy level.There is differences risk factors of stunting between ridge and coastal.
\end{abstract}

Key words: coastal, ridge, stunting.

\begin{abstract}
ABSTRAK
Tujuan penelitian untuk menganalisis perbedaan faktor risiko stunting pada anak usia 2-5 tahun di wilayah gunung dan pesisir. Penelitian menggunakan desain cross sectional. Jumlah subjek sebanyak 114 subjek di wilayah gunung dan 114 subjek di wilayah pesisir yang dipilih secara pusposive dan terdiri dari 57 kasus dan 57 kontrol. Faktor risiko kejadian stunting di wilayah gunung adalah tingkat kecukupan protein yang rendah $(\mathrm{PR}=4,8 ; 95 \% \mathrm{CI}=2,096-10,99)$, tingkat kecukupan $\mathrm{Zn}$ yang rendah $(\mathrm{PR}=2,827 ; 95 \% \mathrm{CI}=1,499-5,322)$, tingkat kecukupan $\mathrm{Fe}$ yang rendah ( $\mathrm{PR}=3,766$; 95\% $\mathrm{CI}=1,785-7,944)$, dan ASI tidak eksklusif ( $\mathrm{PR}=1,626$; $95 \% \mathrm{CI}=1,15-2,299)$. Faktor risiko kejadian stunting di wilayah pesisir yakni tingkat kecukupan energi yang rendah $(\mathrm{PR}=3,463 ; 95 \% \mathrm{CI}=1,648-7,278)$, tingkat kecukupan $\mathrm{Zn}$ yang rendah $(\mathrm{PR}=1,973 ; 95 \% \mathrm{CI}=1.282-$ 3,038), dan tingkat kecukupan $\mathrm{Fe}$ yang rendah ( $\mathrm{PR}=2,033 ; 95 \% \mathrm{CI}=1,003-4,120)$. Faktor risiko yang berhubungan paling kuat dengan kejadian stunting di wilayah gunung adalah pemberian ASI tidak eksklusif dan tingkat kecukupan protein yang rendah. Faktor risiko yang berhubungan paling kuat kejadian stunting di wilayah pesisir adalah tingkat kecukupan protein yang rendah. Terdapat perbedaan faktor risiko kejadian stunting di wilayah gunung dan pesisir.
\end{abstract}

Kata Kunci: gunung, pesisir, stunting.

\section{PENDAHULUAN}

Seseorang dikatakan stunting jika skor

Z kurang dari -2 SD berdasarkan indeks

$\mathrm{TB} / \mathrm{U}$ dan mengindikasi masalah gizi yang sifatnya kronis sebagai akibat kekurangan zat gizi yang berlangsung lama yang mengakibatkan anak menjadi pendek. Prevalensi pendek pada balita 
tahun 2013 menurut provinsi menunjukan Provinsi NTT sebagai provinsi dengan prevalensi stunting tertinggi yakni 51,7\% (26,2\% sangat pendek dan $25,5 \%$ pendek) (Kemenkes RI 2013). Anak usia 2-5 tahun perlu mendapatkan perhatian khusus mengenai kebutuhan gizinya karena pada usia ini anak mengalami pertumbuhan dan perkembangan yang pesat dan masa ini adalah masa di mana anak tidak diberikan ASI lagi sehingga kebutuhan zat gizi hanya dapat dipenuhi dari makanan.

Penyebab langsung terjadinya stunting adalah penyakit infeksi dan tingkat asupan zat gizi (Supariasa 2012). Asupan zat gizi yang sangat berpengaruh terhadap pertumbuhan linear anak adalah protein (Picauly \& Toy 2013), seng (Anindita 2012), zat besi (Stiltzfus 2003), dan vitamin A (Mikhail 2013). Secara teoritis perbedaan topografi memberikan kekhasan pada pola makan masyarakat disebabkan ketersediaan pangan di wilayah yang berbeda (Auliya et al. 2015). Daerah gunung dan perbukitan dominan dengan sayur mayur dan hasil perkebunan sedangkan masyarakat di daerah pesisir pantai cenderung mengkonsumsi makanan hewani yang bersumber dari laut (Khomsan et al. 2006). Selain itu, hasil penelitian di Kabupaten Lumajang tahun 2012 dimana dilakukan pemetaan tingkat kerentanan daerah terhadap penyakit menunjukan adanya perbedaan tingkat kerentanan penyakit infeksi (diare) berdasarkan ketinggian tempat (Fitria et al. 2014).

Kabupaten Kupang memiliki topografi sebagian wilayah gunung dan sebagiannya daerah pesisir dengan stunting balita 51,4\% (Depkes RI 2009) dan merupakan kabupaten dengan jumlah rumah tangga miskin tertinggi di NTT tahun 2013 yang mengakibatkan pengadaan bahan makanan bergantung pada potensi alam disekitarnya (BPS 2016). Jika perbedaan geografis mempengaruhi ketersediaan pangan dan penyakit infeksi maka kemungkinan faktor risiko stunting pada kedua wilayah ini akan berbeda.

Tujuan penelitian ini adalah untuk menganalisis perbedaan faktor risiko stunting pada anak usia 2-5 tahun di wilayah gunung dan pesisir pantai.

\section{METODE}

\section{Desain, Tempat dan Waktu Penelitian}

Penellitian menggunakan desain cross sectional. Penelitian dilakukan di wilayah kerja Puskesmas Oelbiteno Kecamatan Fatuleu Tengah untuk wilayah gunung dan wilayah kerja Puskesmas Batakte Kecamatan Kupang Barat (Desa Sumlili, Desa Tablolong, Desa Lifuleo, Desa Bolok, dan Desa Nitneo) untuk wilayah 
pesisir pantai. Penelitian dilakukan pada bulan September sampai bulan November 2016 setelah mendapatkan izin dari Komisi Etik Penelitian Kesehatan Fakultas Kedokteran Universitas Diponegoro dengan nomor 817/EC/FKRSDK/2016 pada bulan Agustus 2016.

\section{Teknik Pengambilan Data dan Sumber} Data

Subjek penelitian adalah balita usia 23 tahun. Subyek dipilih secara purposiv sebanyak 114 balita di wilayah gunung dan 114 balita di wilayah pesisir pantai yang terdiri dari 57 balita stunting dan 57 balita normal untuk masing-masing wilayah. Data yang diambil adalah data primer dan data sekunder. Data primer antara lain data tinggi badan, data asupan makanan, data riwayat ASI eksklusif, dan riwayat kejadian infeksi. Tinggi badan balita diukur menggunakan stadiometer, data asupan makanan diambil dengan menggunakan FFQ semikuantitatif. Data kejadian penyakit infeksi yang diambil adalah kejadian ISPA dan diare yang diambil dengan menggunanakan kuisioner dalam 1 bulan terakhir, serta data riwayat ASI eksklusif yang diambil dengan menggunakan kuisioner. Data sekunder meliputi jumlah balita yang diperoleh melalui buku register posyandu.

\section{Pengolahan dan Analisis Data}

Subjek dikategorikan stunting jika skor $\mathrm{Z}$ untuk $\mathrm{TB} / \mathrm{U}<-2 \mathrm{SD}$ dan normal jika skor $Z \geq-2 S D$. Cut off point untuk energi dan protein adalah cukup jika asupan $\geq 90 \%$ AKG dan kurang jika < 90\% AKG (Ghaida 2014), sedangkan cut off point untuk tingkat kecukupan mikronutrien adalah cukup jika konsumsi $\geq 77 \%$ AKG dan kurang jika $<77 \%$ AKG (Gibson 2005). Analisis bivariat dengan menggunakan chi square dengan kemaknaan 95\%. Analisis multivariat menggunakan regresi logistik (Sopyudin 2011).

\section{HASIL DAN PEMBAHASAN}

\section{Gambaran Karakteristik Responden}

Tabel 1 menunjukan, di wilayah gunung proporsi perempuan lebih banyak mengalami stunting dibandingkan dengan laki-laki, sedangkan di wilayah pesisir proporsi laki-laki lebih banyak mengalami stunting dibandingkan dengan perempuan. Hasil analisis dengan chi square menunjukan tidak ada perbedaan proporsi jenis kelamin antara kelompok kasus dan kelompok kontrol di wilayah gunung dan pesisir $(p>0,05)$. Tabel 1 menunjukan tidak ada perbedaan umur balita dan tingkat pendidikan ibu antara kelompok kasus dan kelompok kontrol di wilayah gunung dan pesisir pantai $(\mathrm{p}>0,05)$. 
Tabel 2 menunjukan bahwa sebagian besar ibu balita di wilayah gunung bekerja sebagai petani sedangkan di wilayah pesisir sebagian besar ibu balita adalah ibu rumah tangga.

\section{Faktor Risiko Stunting}

Tabel 3 menunjukan bahwa faktor risiko kejadian stunting di wilayah gunung antara lain tingkat kecukupan protein yang rendah, tingkat kecukupan $\mathrm{Zn}$ yang rendah, tingkat kecukupan $\mathrm{Fe}$ yang rendah dan pemberian ASI tidak eksklusif sedangkan faktor risiko kejadian stunting di wilayah pesisir antara lain tingkat kecukupan energi yang rendah, tingkat kecukupan $\mathrm{Zn}$ yang rendah, dan tingkat kecukupan $\mathrm{Fe}$ yang rendah. Terdapat perbedaan faktor risiko kejadian stunting di wilayah gunung dan pesisir pantai yakni tingkat kecukupan energi dan tingkat kecukupan protein serta riwayat ASI eksklusif.

Tabel 1. Umur balita dan pendidikan ibu berdasarkan wilayah

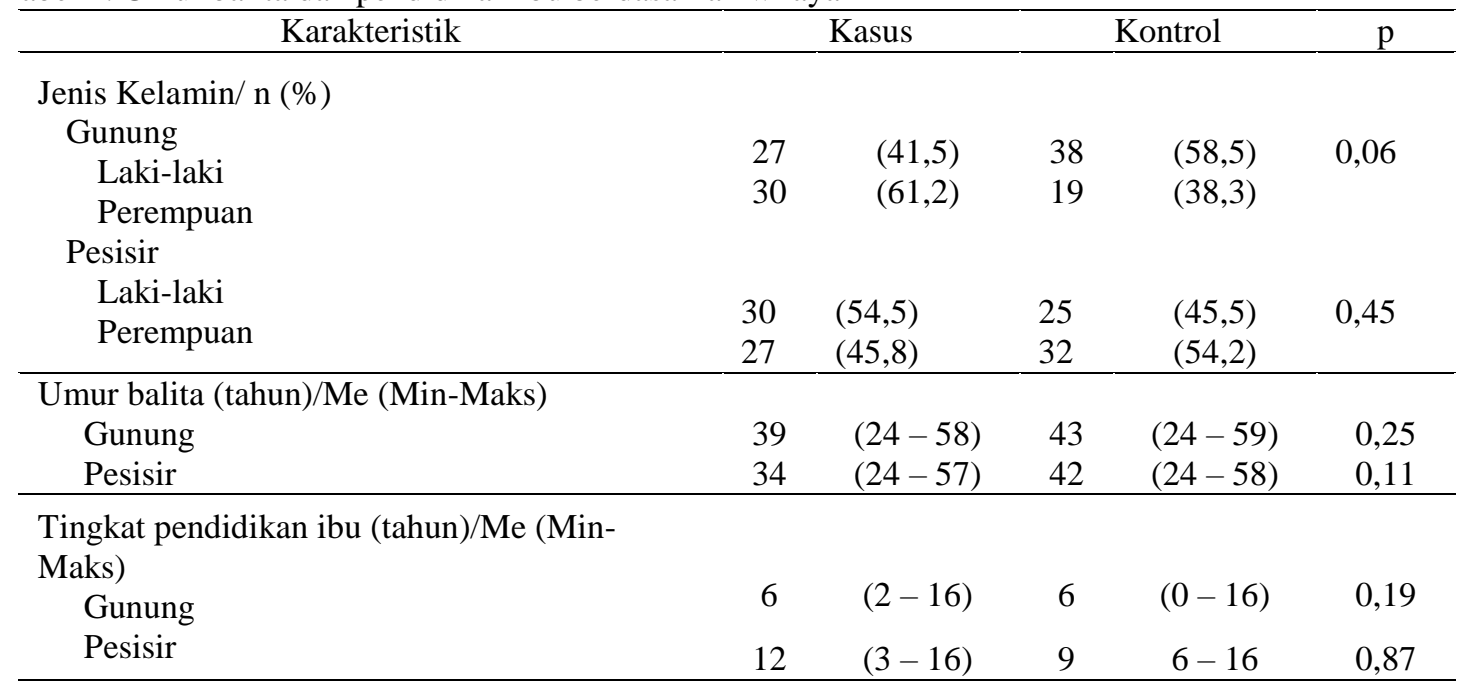

Tabel 2. Jenis pekerjaan ibu berdasarkan kelompok dan wilayah

\begin{tabular}{llll}
\hline Jenis pekerjaan ibu & Kasus $\mathrm{n}(\%)$ & Kontrol $\mathrm{n}(\%)$ & Total $\mathrm{n}(\%)$ \\
\hline Gunung: & & & \\
Petani & $40(64,5)$ & $22(35,5)$ & $62(54,4)$ \\
Pegawai pemerintahan & $5(71,4)$ & $2(28,6)$ & $7(6,1)$ \\
IRT & $11(26,2)$ & $31(73,8)$ & $42(36,8)$ \\
Lainnya & $1(33,3)$ & $2(66,7)$ & $3(2,6)$ \\
Pesisir: & & & \\
Petani & $2(100)$ & $0(0)$ & $2(1,75)$ \\
Pegawai pemerintahan & $1(50)$ & $1(50)$ & $2(1,75)$ \\
IRT & $52(49,1)$ & $54(50,9)$ & $106(93)$ \\
Lainnya & $2(50)$ & $2(50)$ & $4(3,5)$ \\
\hline
\end{tabular}


Tabel 3. Analisis faktor risiko stunting

\begin{tabular}{|c|c|c|c|c|}
\hline Faktor Risiko & Kasus n(\%) & Kontrol n(\%) & $\mathrm{p}$ & PR $(95 \%$ CI $)$ \\
\hline \multicolumn{5}{|c|}{ Tingkat kecukupan energi: } \\
\hline \multicolumn{5}{|c|}{ Gunung } \\
\hline Kurang & $48(54,5)$ & $40(45,5)$ & \multirow[t]{2}{*}{0,12} & 1,58 \\
\hline cukup & $9(34,6)$ & $17(65,4)$ & & $(0,9-2,76)$ \\
\hline \multicolumn{5}{|l|}{ Pesisir } \\
\hline Kurang & $51(63)$ & $30(37)$ & \multirow[t]{2}{*}{$\mathbf{0 , 0 1}$} & 3,46 \\
\hline Cukup & $6(18,2)$ & $27(81,8)$ & & $(1,65-7,28)$ \\
\hline \multicolumn{5}{|c|}{ Tingkat kecukupan protein: } \\
\hline \multicolumn{5}{|c|}{ Gunung } \\
\hline Kurang & $52(66,7)$ & $26(33,3)$ & \multirow[t]{2}{*}{$\mathbf{0 , 0 1}$} & 4,8 \\
\hline cukup & $5(13,9)$ & $31(86,1)$ & & $(2,1-11)$ \\
\hline \multicolumn{5}{|l|}{ Pesisir } \\
\hline Kurang & $15(60)$ & $10(40)$ & \multirow[t]{2}{*}{0,37} & 1,27 \\
\hline Cukup & $42(47,2)$ & $47(52,8)$ & & $(0,86-1,88)$ \\
\hline \multicolumn{5}{|c|}{ Tingkat kecukupan vit. A: } \\
\hline Gunung & & & & \\
\hline Kurang & $5(71,4)$ & $2(28,6)$ & \multirow[t]{2}{*}{0,44} & 1,47 \\
\hline cukup & $52(48,6)$ & $55(51,4)$ & & $(0,89-2,44)$ \\
\hline \multicolumn{5}{|l|}{ Pesisir } \\
\hline Kurang & $1(50)$ & $1(50)$ & \multirow[t]{2}{*}{1} & 1 \\
\hline Cukup & $56(50)$ & $56(50)$ & & $(0,25-4,05)$ \\
\hline \multicolumn{5}{|c|}{ Tingkat kecukupan $\mathrm{Zn}$ : } \\
\hline Gunung & & & & \\
\hline Kurang & $49(62,8)$ & $29(37,2)$ & \multirow[t]{2}{*}{$\mathbf{0 , 0 1}$} & 2,83 \\
\hline cukup & $8(22,2)$ & $28(77,8)$ & & $(1,5-5,32)$ \\
\hline \multicolumn{5}{|l|}{ Pesisir } \\
\hline Kurang & $40(61,7)$ & $22(38,3)$ & \multirow[t]{2}{*}{$\mathbf{0 , 0 1}$} & 1,97 \\
\hline Cukup & $17(37,0)$ & $35(63,0)$ & & $(1.28-3,04)$ \\
\hline \multicolumn{5}{|c|}{$\begin{array}{l}\text { Tingkat kecukupan Fe: } \\
\text { Gunung }\end{array}$} \\
\hline Kurang & $51(64,6)$ & $28(35,4)$ & 0,01 & 3,77 \\
\hline cukup & $6(17,1)$ & $29(82,9)$ & & $(1,79-7,94)$ \\
\hline Pesisir & & & & \\
\hline Kurang & $51(55,4)$ & $41(44,6)$ & $\mathbf{0 , 0 3}$ & 2,03 \\
\hline Cukup & $6(27,3)$ & $16(72,7)$ & & $(1,01-4,12)$ \\
\hline Kejadian ISP & & & & \\
\hline Gunung & & & & \\
\hline $\mathrm{Ya}$ & $38(50,7)$ & $37(49,3)$ & 1 & 1,04 \\
\hline Yidak & $19(48,7)$ & $20(51,3)$ & & $(0,7-1,54)$ \\
\hline Pesisir & & & & \\
\hline $\mathrm{Ya}$ & $35(53)$ & $31(47)$ & 0,57 & 1,16 \\
\hline Tidak & $22(45,8)$ & $26(54,2)$ & & $(0,79-1,7)$ \\
\hline Kejadian Diare & & & & \\
\hline Gunung & & & & \\
\hline $\mathrm{Ya}$ & $9(52,9)$ & $8(47,1)$ & 1 & 1,07 \\
\hline Yidak & $48(49,5)$ & $49(50,5)$ & & $(0,66-1,75)$ \\
\hline Pesisir & & & & \\
\hline $\mathrm{Ya}$ & $9(69,2)$ & $4(30,8)$ & 0,24 & 1,46 \\
\hline Tidak & $48(47,5)$ & $53(52,5)$ & & $(0,96-2,21)$ \\
\hline Riwayat ASI el & & & & \\
\hline Gunung & & & & \\
\hline Tidak & $25(67,6)$ & $12(32,4)$ & $\mathbf{0 , 0 2}$ & 1,63 \\
\hline $\mathrm{Ya}$ & $32(41,6)$ & $45(58,4)$ & & $(1,15-2,3)$ \\
\hline Pesisir & & & & \\
\hline Tidak & $24(43,6)$ & $31(56,4)$ & 0,26 & 0,78 \\
\hline $\mathrm{Ya}$ & $33(55,9)$ & $26(44,1)$ & & $(0,54-1,14)$ \\
\hline
\end{tabular}


Hasil analisis menunjukan tingkat kecukupan energi yang rendah bukan merupakan faktor risiko kejadian stunting di wilayah gunung. Penyebab kejadian stunting bukan hanya dari konsumsi energi yang rendah, tetapi ada juga penyebab lain yaitu tingkat kecukupan protein, Zn, dan Fe yang rendah. Makanan yang menghasilkan energi paling banyak adalah makanan sumber lemak dan yang kedua adalah makanan sumber karbohidrat (Almatsier 2009). Sebagian besar masyarakat di daerah gunung lebih banyak mengkonsumsi makanan sumber karbohidrat dan lemak dari serealia seperti jagung, umbi-umbian dan kacangkacangan. Makanan hasil pertanian ini merupakan makanan yang dikonsumsi oleh masyarakat. Hal ini dilakukan untuk menekan pengeluaran untuk konsumsi sehari-hari. Jadi bahan makanan yang digunakan untuk konsumsi sehari-hari adalah dari hasil olah tanah. Dengan demikian dapat dikatakan bahwa masyarakat gunung dapat memenuhi kebutuhan energi dari konsumsi hasil pertanian yang diproduksi. Penelitian yang dilakukan di daerah gunung ini sejalan dengan penelitian yang dilakukan di Kabupaten Jember yang menunjukan tidak ada hubungan antara tingkat kecukupan energi dengan kejadian stunting ( $>0,05)$ (Aridiyah et al. 2015). Demikian pula penelitian yang dilakukan di Kabupaten Cianjur yang menunjukan tidak ada hubungan yang signifikan antara tingkat kecukupan energi dengan kejadian stunting ( $>>0,05)$ (Hanum et al. 2014)

Berbeda dengan daerah gunung, tingkat kecukupan energi yang rendah merupakan faktor risiko kejadian stunting di wilayah pesisir dengan nilai PR sebesar 3,463 yang berarti subyek yang tingkat kecukupan energinya kurang memiliki risiko 3,463 kali mengalami stunting. Energi sangat diperlukan dalam proses pertumbuhan. Energi diperlukan untuk pembentukan jaringan-jaringan baru serta metabolisme di dalam sel. Kekurangan energi dapat menyebabkan penghambatan pertumbuhan. Penelitian ini sejalan dengan penelitian yang dilakukan di Sumatera menunjukan bahwa tingkat kecukupan energi yang rendah merupakan faktor risiko stunting dengan nilai OR sebesar 1,28 (95\% CI=1,01-1,59) yang berarti anak dengan tingkat kecukupan energi yang rendah berisiko mengalami stunting 1,28 kali dibandingkan anak yang mengkonsumsi cukup energi (Oktarina \& Sudiarti 2013).

Hasil analisis memberikan informasi bahwa tingkat kecukupan protein yang rendah merupakan faktor risiko kejadian 
stunting di wilayah gunung dengan nilai PR sebesar 4,8 yang berarti subyek yang tingkat kecukupan proteinnya kurang memiliki risiko 4,8 kali mengalami stunting. Sebagian besar balita di wilayah gunung memiliki tingkat kecukupan protein yang rendah, hal ini dikarenakan kurangnya mengkonsumsi pangan hewani. Jenis pangan yang dikonsumsi oleh masyarakat gunung sebagian besar adalah pangan nabati sebagai hasil olah tanah seperti ubi, sayur, dan sebagainya. Sumber protein yang digunakan sebagaian besar berasal kacang-kacangan karena merupakan hasil pertanian masyarakat setempat. Dimana kandungan protein dalam bahan pangan nabati lebih rendah dibandingkan dengan bahan pangan hewani (Muchtadi 2009).

Protein selain sebagai sumber energi juga berfungsi sebagai zat pembangun dan pengatur di dalam tubuh. Fungsi utama protein di dalam tubuh antara lain untuk pertumbuhan dan pemeliharaan jaringan matriks atau kerangka tulang dan gigi, di mana kalsium dan fosfor disimpan untuk memberikan kekuatan dan rigiditas jaringan adalah protein (Almatsier 2009). Hasil penelitian yang dilakukan di daerah gunung sejalan dengan penelitian yang dilakukan di wilayah kumuh Kota Surakarta yang menunjukan bahwa tingkat kecukupan protein yang rendah merupakan faktor risiko kejadian stunting $(\mathrm{p}<0,05)$ dengan nilai OR sebesar 3,46 $(95 \% \mathrm{CI}=1,361-8,751)$ yang berarti balita dengan tingkat kecukupan protein yang kurang memiliki risiko mengalami stunting 3,46 kali dibandingkan dengan balita dengan tingkat kecukupan protein yang cukup (Hidayati et al. 2010).

Hasil analisis menunjukan bahwa tingkat kecukupan protein yang rendah bukan merupakan faktor risiko kejadian stunting di wilayah pesisir dikarenakan sebagian besar subyek mengkonsumsi cukup protein yang bersumber dari laut seperti ikan, kerang, cumi-cumi dan sebagainya. Selain itu, bila protein dikaitkan dengan status gizi berdasarkan TB/U, ada anak-anak yang nilai TB/U nya kurang namun memiliki asupan protein yang baik, dan ada juga anak-anak yang memiliki skor TB/U yang baik namun saat ini memiliki asupan protein yang rendah. Konsumsi protein tidak secara langsung berkaitan dengan tinggi badan karena tinggi badan merupakan gambaran status gizi masa lampau sehingga kemungkinan anak mengalami kekurangan protein pada masa lampau. Hasil penelitian di wilayah pesisir ini sejalan dengan penelitian yang dilakukan di Sumatera yang menunjukan bahwa tingkat kecukupan protein yang rendah bukan merupakan faktor risiko 
kejadian stunting $(\mathrm{p}>0,05)$ (Oktarina \& Sudiarti 2013).

Hasil analisis menunjukan bahwa tingkat kecukupan vitamin A yang rendah bukan merupakan fakor risiko kejadian stunting di wilayah gunung dan pesisir pantai. Hal ini disebabkan karena sebagian besar balita mengkonsumsi sayuran hijau di setiap kali makannya seperti daun singkong, daun pepaya, sawi, kangkung dan bayam dan sering mengkonsumsi buah-buahan yang berwarna kuningjingga seperti pepaya, mangga, tomat, jagung kuning, dan jeruk yang kaya akan karoten. Hasil penelitian ini sejalan dengan penelitian yang dilakukan di wilayah Surakarta yang menunjukan tingkat kecukupan vitamin A yang rendah bukan merupakan faktor risiko stunting (95\% CI=0,622-3,968) (Hidayati et al. 2010).

Hasil analisis menunjukan bahwa tingkat kecukupan $\mathrm{Zn}$ yang rendah merupakan faktor risiko kejadian stunting di wilayah gunung dengan PR sebesar 2,827 yang berarti subyek dengan tingkat kecukupan Zn yang rendah memiliki risiko 2,827 kali mengalami stunting. Sedangkan hasil analisis menunjukan bahwa tingkat kecukupan Zn yang rendah merupakan faktor risiko kejadian stunting di wilayah pesisir dengan nilai PR sebesar 1,973 yang berarti subyek dengan tingkat kecukupan Zn yang rendah berisiko 1,973 kali mengalami stunting.

Kekurangan seng pada saat anak-anak dapat menyebabkan stunting (pendek). Seng memperlancar efek vitamin D terhadap metabolisme tulang melalui stimulasi sintesis DNA di sel-sel tulang. Oleh karena itu, seng sangat erat kaitannya dengan metabolisme tulang, sehingga seng berperan secara positif pada pertumbuhan dan perkembangan (Anindita 2012). Hasil penelitian ini sejalan dengan hasil penelitian yang dilakukan di Kota Surakarta yang menunjukan bahwa tingkat kecukupan $\mathrm{Zn}$ yang rendah merupakan faktor risiko kejadian stunting dengan OR sebesar 2,67 (95\% CI=1,129-6,298) yang berarti subyek dengan tingkat kecukupan $\mathrm{Zn}$ yang rendah memiliki risiko 2,67 kali mengalami stunting dibandingkan dengan subyek yang memiliki tingkat kecukupan Zn yang cukup (Hidayati et al. 2010).

Hasil analisis menunjukan bahwa tingkat kecukupan $\mathrm{Fe}$ yang rendah merupakan faktor risiko kejadian stunting di wilayah gunung dengan PR sebesar 3,766 yang berarti subyek dengan tingkat kecukupan $\mathrm{Fe}$ yang rendah memiliki risiko 3,766 kali mengalami stunting. Sedangkan hasil analisis menunjukan bahwa tingkat kecukupan Fe yang rendah merupakan faktor risiko kejadian stunting 
di wilayah pesisir dengan nilai PR sebesar 2,033 yang berarti subyek dengan tingkat kecukupan Fe yang rendah berisiko 2,033 kali mengalami stunting.

Fe adalah salah satu jenis zat gizi yang penting bagi tubuh yang merupakan penyusun dari hemoglobin dalam sel darah merah dan mioglobin yang secara cepat mendistribusikan oksigen dan penyimpanan oksigen di otot dan jaringan. Selain itu, zat besi diperlukan dalam pembentukan kolagen yang diperlukan untuk pembentukan tulang, gigi, sendi, otot dan kulit. Sehingga kekurangan zat besi dapat menyebabkan perawakan pendek pada anak (Muchtadi 2009). Hasil penelitian ini sejalan dengan penelitian yang dilakukan di Kota Surakarta menunjukan tingkat asupan $\mathrm{Fe}$ yang rendah merupakan faktor risiko kejadian stunting dengan nilai OR sebesar 3,25 $(95 \%$ IC $=1,333-7,898)$ yang berarti balita dengan tingkat kecukupan zat besi yang rendah memiliki risiko 3,25 kali mengalami stunting dibandingkan balita dengan tingkat kecukupan Fe yang cukup (Hidayati 2010).

Hasil analisis menunjukan bahwa kejadian ISPA bukan merupakan faktor risiko kejadian stunting di wilayah gunung dan pesisir pantai, hal ini disebabkan karena proporsi kejadian ISPA pada kelompok kasus dan kontrol hampir sama, selain itu durasi ISPA yang relatif lebih singkat yakni 3-4 hari. Bukan hanya kejadian ISPA saja yang menjadi penyebab kejadian stunting, adapun faktor lain yang dapat menyebabkan terjadinya stunting selain ISPA yaitu kurangnya mengkonsumsi zat gizi yang adekuat. Walaupun bukan merupakan faktor risiko kejadian stunting di wilayah gunung dan pesisir pantai namun proporsi balita yang mengalami ISPA lebih banyak pada kelompok kasus dibandingkan dengan kelompok kontrol di wilayah gunung dan pesisir pantai. Hasil penelitian ini sejalan dengan penelitian yang dilakukan di Kalimantan Barat yang menunjukan bahwa kejadian ISPA bukan merupakan faktor risiko kejadian stunting $(\mathrm{OR}=0,58$; 95\% CI=0,280-1,192) (Wahdah et al. 2014).

Hasil analisis menunjukan bahwa kejadian diare bukan merupakan faktor risiko kejadian stunting di wilayah gunung dan pesisir pantai. Walaupun bukan merupakan faktor risiko kejadian stunting, namun proporsi balita yang mengalami diare lebih banyak pada kelompok kasus baik itu di wilayah gunung maupun pesisir pantai. Kemungkinan adanya penyebab langsung lainnya yang menjadi penyebab kejadian stunting yakni tingkat asupan zat gizi yang rendah. Anak yang mengalami diare apabila diberikan asupan zat gizi 
yang memadai maka akan menurunkan risiko terjadinya malnutrisi, begitupun sebaliknya, anak yang tidak diare namun tidak diberikan asupan zat gizi yang baik akan meningkatkan risiko terjadinya malnutrisi pada anak. Hasil penelitian ini sejalan dengan penelitian yang dilakukan di wilayah Kalimantan Barat yang menunjukan bahwa kejadian diare bukan merupakan faktor risiko kejadian stunting $(\mathrm{OR}=0,871 ; \quad 95 \% \quad \mathrm{CI}=0,42-1,830)$ (Wahdah et al. 2014).

Hasil analisis menunjukan pemberian ASI tidak eksklusif merupakan faktor risiko kejadian stunting di wilayah gunung dengan nilai PR sebesar 1,626 yang berarti subyek yang tidak diberikan ASI eksklusif memiliki risiko 1,626 kali mengalami stunting. Sebagian besar ibu balita di wilayah gunung bermata pencaharian sebagai petani sehingga waktu yang dimiliki sebagian besar dihabiskan untuk bertani, apalagi memasuki musim tanam maka aktivitas ibu lebih banyak di kebun membantu suaminya bekerja. Ketika bekerja, ibu akan meninggalkan anaknya di rumah dan dirawat oleh mertua di rumah. Hal ini membuat sebagian besar ibu memberhentikan pemberian ASI kepada anaknya sebelum anak berusia 6 bulan.

ASI dan plasma memiliki konsentrasi ion yang sama sehingga bayi tidak memerlukan cairan atau makanan tambahan. ASI memiliki semua unsurunsur yang memenuhi kebutuhan bayi akan gizi selama periode sekitar 6 bulan, kecuali jika ibu megalami keadaan gizi kurang yang berat atau gangguan kesehatan lain. ASI mengandung lemak dalam bentuk asam amino esensial, asam lemak jenuh, trigliserida rantai sedang, dan kolesterol dalam jumlah yang mencukupi kebutuhan bayi sehingga dapat mengoptimalkan pertumbuhan bayi. Hal ini menyebabkan anak yang diberikan ASI eksklusif memiliki pertumbuhan yang lebih baik dibandingkan dengan anak yang tidak diberikan ASI eksklusif (Brown et al. 2005). Hasil penelitian ini sejalan dengan penelitian yang dilakukan di Kalimantan Barat yang menunjukan bahwa pemberian ASI yang tidak eksklusif merupakan faktor kejadian stunting dengan nilai OR sebesar 2,02 $(95 \%$ IC $=1,329-3,689)$ yang berarti anak yang tidak memperoleh ASI eksklusif memiliki risiko 2,09 kali mengalami stunting (Wahdah 2014).

Berbeda dengan wilayah gunung, pemberian ASI yang tidak eksklusif bukan merupakan faktor risiko kejadian stunting di wilayah pesisir pantai, bahkan proporsi balita yang tidak diberikan ASI eksklusif lebih banyak pada kelompok kontrol. Anak yang tidak memperoleh ASI ekslusif 
namun diberikan makanan pendamping yang tepat dapat memperbaiki status gizinya. Kemungkinan pemberian MPASI serta makanan yang tepat dapat menurunkan risiko terjadinya malnutrisi pada anak. Hasil penelitian ini sejalan dengan penelitian yang dilakukan di Kabupaten Hulu Sungai Utara yang menemukan bahwa pemberian ASI yang tidak eksklusif bukan merupan faktor risiko kejadian stunting ( $\mathrm{p}>0,05)$ (Rahayu et al. 2016).

\section{Analisis multivariat}

Tabel 4. Analisis multivariat faktor risiko stunting wilayah gunung dan pesisir pantai

\begin{tabular}{|c|c|c|c|c|c|}
\hline \multirow{2}{*}{ Faktor risiko } & \multirow{2}{*}{ Koefisien } & \multirow{2}{*}{$\mathrm{p}$} & \multirow{2}{*}{ OR } & \multicolumn{2}{|c|}{ IK $95 \%$} \\
\hline & & & & Min & Maks \\
\hline $\begin{array}{l}\text { Gunung: } \\
\text { ASI eks }\end{array}$ & 1,47 & 0,01 & 4,35 & 1,51 & 12,510 \\
\hline TKP & 2,01 & 0,01 & 7,46 & 2,03 & 27,349 \\
\hline TKFe & 1,256 & 0,05 & 3,51 & 0,99 & 12,364 \\
\hline Konstanta & $-2,83$ & 0,01 & 0,06 & & \\
\hline $\begin{array}{l}\text { Pesisir: } \\
\text { TKE }\end{array}$ & 2,04 & 0,01 & 7,65 & 2,83 & 20,65 \\
\hline Konstanta & $-1,5$ & 0,01 & 0,22 & & \\
\hline
\end{tabular}

Tabel 4 menunjukan bahwa variabel yang paling berpengaruh terhadap kejadian stunting di wilayah gunung adalah tingkat kecukupan protein yang rendah serta riwayat ASI tidak eksklusif sedangkan faktor risiko yang paling berpengaruh terhadap kejadian stunting di wilayah pesisir adalah tingkat kecukupan energi yang rendah.

\section{Perbedaan faktor risiko stunting antara wilayah gunung dan pesisir}

Terdapat perbedaan faktor risiko stunting antara wilayah gunung dan pesisir pantai antara lain tingkat kecukupan energi dan protein serta riwayat pemberian ASI eksklusif.
Perbedaan letak geografis berpengaruh terhadap ketersediaan pangan rumah tangga sehingga terdapat perbedaan konsumsi zat gizi. Daerah gunung dan perbukitan yang sesuai untuk daerah pertanian dominan dengan sayur mayur dan hasil perkebunan sedangkan masyarakat pesisir cenderung mengkonsumsi makanan hewani yang bersumber dari laut (Khomsan 2006). Salah satu faktor ekstern pembentuk perilaku manusia adalah lingkungan fisik seperti iklim dan keadaan geografis di sekitar manusia. Hal ini mengkibatkan perbedaan geografis berimplikasi pada sosiodemografi masyarakat dalam hal jenis pekerjaan yang berpengaruh pada 
perawatan anak (Handayani 2012). Sebagian besar masyarakat gunung bekerja sebagai petani. Berbeda dengan nelayan, bertani adalah pekerjaan yang dapat dilakukan oleh laki-laki dan perempuan (Tim PSG STAIN Pekalongan 2010) sedangkan nelayan penangkapan dilakukan oleh laki-laki (Handajani et al. 2015). Hal ini menyebabkan sebagian besar ibu balita di wilayah gunung berprofesi sebagai petani membantu suami bekerja di kebun dan meluangkan sedikit waktu mereka untuk anak di rumah sehingga berdampak pada tidak diberikan ASI eksklusif kepada anak mereka.

\section{KESIMPULAN}

Faktor risiko kejadian stunting di wilayah gunung antara lain tingkat kecukupan protein yang rendah, tingkat kecukupan $\mathrm{Zn}$ yang rendah, tingkat kecukupan Fe yang rendah dan pemberian ASI tidak eksklusif. Faktor risiko kejadian stunting di wilayah pesisir antara lain tingkat kecukupan protein yang rendah, tingkat kecukupan $\mathrm{Fe}$ yang rendah, dan tingkat kecukupan $\mathrm{Zn}$ yang rendah. Terdapat perbedaan faktor risiko kejadian stunting di wilayah gunung dan pesisir pantai yakni tingkat kecukupan energi, tingkat kecukupan protein dan riwayat ASI eksklusif.

\section{UCAPAN TERIMA KASIH}

Terima kasih kepada kepala dan staf Puskesmas Oelbiteno dan Puskesmas Batakte serta kepada orang tua subjek yang telah berpartisipasi dalam penelitian ini.

\section{DAFTAR PUSTAKA}

Adriani M, Wijatmadi B. 2012 Pengantar gizi masyarakat edisi pertama. Jakarta: Kencana Prenada Media Group. 1-41, 145-200.

Almatsier S. 2009. Prinsip dasar ilmu gizi. Jakarta: Gramedia Pustaka Utama.

Anindita P. 2012. Hubungan tingkat pendidikan ibu, pendapatan keluarga, kecukupan protein dan zink dengan stunting (pendek) pada balita usia 6-35 bulan di Kecamatan Tembalang Kota Semarang. Jurnal Kesehatan Masyarakat. 1 (2): 617626.

Aridiyaf FO, Rohmawati N, Ririanti M. 2015. Faktor-faktor yang mempengaruhi kejadian stunting pada anak balita di wilayah pedesaan dan perkotaan. e-Jurnal Pustaka Kesehatan. 3 (1): 163-170.

Auliya C, Woro OK, Budiono I. 2015. Profil status gizi balita ditinju dari topografi wilayah tempat tinggal (studi di wilayah pantai dan wilayah punggung bukit Kabupaten Jepara). Unnes Journal of Public Health. 4 (2). 108-116.

BPS. Jumlah penduduk miskin menurut kabupaten/kota tahun 2005-2013 (000 orang). Http://ntt.bps.go.id. [diakses pada tanggal 20 juni 2016]

Brown JE, Dugan C, Kleindan R. 2005. Nutrition through the life cycle. Balmont, USA: Thomson Wadsworth.

DepKes RI. 2009. Laporan hasil riskesdas Provinsi Nusa Tenggara Timur tahun 2008. Badan Penelitian dan Pengembangan Kesehatan.

Fitria L, Wahjudi P, Wati DM. 2014. Pemetaan tingkat kerentanan daerah terhadap penyakit menular (TB paru, DBD, dan Diare) di Kabupaten Lumajang tahun 2012. E-jurnal pustaka kesehatan. 2 (1): 460-467.

Ghaida Y, Lilik K, Cesilia MD. 2014. Risk factors of stunting among school-aged children from eight provinces in Indonesia. Pakistan Journal of Nutrition. 13 (10): 557-566. 
Gibson RS. 2005. Principle of Nutritional and assessment $2^{\text {nd }}$ ed. New York: Oxford University Press.

Handajani H, Relawati R, Handayanto E. 2015. Peran gender dalam keluarga nelayan tradisional dan implikasinya pada model pemberdayaan perempuan di kawasan pesisir Malang Selatan. Jurnal Perempuan dan Anak. 1 (1): 1-21.

Handayani OWK. 2012. Pola asuh gizi ditinjau dari perspektif social budaya dalam pembangunan. Semarang: Unnes Press

Hanum F, Khomsan A, Heryatno Y. 2014. Hubungan asupan gizi dan tinggi badan ibu dengan status gizi anak balita. Jurnal Gizi dan Pangan. 9 (1): 1-6.

Hidayati L, Hadi H, Kumara A. 2010. Kekurangan energi dan zat gizi merupakan faktor risiko kejadian stunted pada anak usia 13 tahun yang tinggal di wilayah kumuh perkotaan Surakarta. Jurnal Kesehatan. 3 (1): 89-104.

Kementrian Kesehatan RI. 2013. Riset Kesehatan Dasar. Badan Penelitian dan Pengembangan Kesehatan.

Mikhail ZA, Sobhy HM, El-Sayed HH. 2013. Effect of nutritional status on growth pattern of stunted preschool children in Egypt. Academic Journal of Nutrition. 2 (1): $1-9$.
Muchtadi D. 2009. Pengantar Ilmu Gizi. Bandung: Alfabeta

Oktarina Z, Sudiarti T. 2013. Faktor risiko stunting pada balita (24-59 bulan) di sumatera. Jurnal gizi dan pangan. 8 (3): 175-180.

Picauly I, Toy SM. 2013. Analisis faktor determinan stunting dan pengaruhnya terhadap prestasi belajar anak sekolah di Kupang da Sumba Timur-NTT. Jurnal Gizi dan Pangan. 8 (1): 55-62.

Rahayu A, et all. 2016. Faktor risiko yang berhubungan dengan kejadian pendek pada anak usia 6 - 24 bulan. Jurnal Kesehatan Masyarakat. 11 (2): 96-103.

Sopiyudin DM. 2011. Statistik untuk kedokteran dan kesehatan. Jakarta: Salemba Medika.

Stiltzfus RJ. 2003. Iron deficiency: Global prevalence and consequences. Food and nutrition bulletin supplement. 24 (4): 99103

Tim PSG STAIN Pekalongan. 2010. Peran perempuan di sektor pertanian. Muwazah. 2 (1): 215-224.

Wahdah S, Juffrie M, Huriyati E. 2014. Faktor risiko kejadian stunting pada anak umur 6-36 bulan di wilayah pedalaman kecamatan silat hulu, Kapuas hulu, Kalimantan barat. Jurnal Gizi dan Dietetika Indonesia. 2 (1): 23-34. 